This is an Accepted Manuscript of an article published by Taylor \& Francis Group in Journal of Marketing Management. Journal of Marketing Management on 16 Apr 2019, available online: http://www.tandfonline.com/10.1080/0267257X.2019.1601124

\author{
Victoria L. Rodner \\ University of Stirling \\ Stirling Management School \\ Stirling, UK - FK9 4AL \\ victoria.rodner@stir.ac.uk \\ Tel: +44 (0)1786466454
}

Chloe Preece (corresponding author)

Royal Holloway, University of London

School of Management

Egham, UK - TW20 0EX

chloe.preece@rhul.ac.uk

Tel: +44 (0)1784414479 


\title{
Consumer Transits and Religious Identities: Towards a Syncretic Consumer
}

\begin{abstract}
The majority of research on religious consumption assumes stable, singular and exclusive preferences, an individual is an adherent to one religion at a time and conversion is a radical break in identity. In examining a context where individuals can simultaneously practice multiple religions despite seemingly theologically incompatible beliefs, we introduce the concept of religious transit, allowing for a more processual understanding of religious identity. To do so, we draw on theories of religious capital, foregrounding the flexibility of this resource in enabling multifarious religious consumption. This is made possible by the religious leaders themselves; in highlighting shared rituals and discourses, they downplay any cognitive incongruences to allow for easy, market-mediated accessibility. By conceptualising four types of religious consumption we theorise the dynamics of consumer mobility.
\end{abstract}

\section{Summary statement of contribution:}

While the literature has demonstrated that postmodern religious consumers can mix and match between various beliefs, there has been little understanding of how the market mediates this movement. By enabling the accumulation and utilisation of religious capital, religions can ease entry and increase participation whilst still remaining differentiated. As such, this research offers significant implications in terms of religious identity, classifying it on a spectrum ranging from fixed, singular identity to impermanent, multifarious identity.

Key words: religious consumption, consumer mobility, religious capital, religious transit, Brazil 


\section{Consumer Transits and Religious Identities: Towards a Syncretic Consumer}

After what feels like an hour of a very lively and seemingly potent spiritual cleansing, the pai-de-santo (father of saint or priest) of this Candomble house asks me to sit in a chair in the corner of the room and look out the window. So far I have had a variety of things done to me by this Afro-Brazilian religious leader: colourful cloths have covered my face during much of the ritual, momentarily blinding me of everything that is happening in this rather gritty venue, beans and corn kernels have been carefully placed in my hand as well as thrown over my body, black candles have been cracked over my head, whilst white and red ones are thrown directly at my feet, aromatic branches have been used to whip the spirits out of me, and strategically placed mounds of gun powder have been lit up to create unexpected bursts of smoke. The grand finale of my spiritual cleansing comes when I am asked to sit on a plastic chair, overlooking the sights of Salvador - the epicenter of AfroBrazilian culture. The pai-de-santo asks me if I am Catholic, to which I instinctively answer 'yes,' although I rarely go to church. 'Then pray Hail Marys' he instructs me and I quickly hark back to my childhood and begin a mantric Hail Mary in a loop... I hear more animated Yoruba in the background as I concentrate on the sights of this derelict city and all of a sudden 'whooosh' a large bucket of uncomfortably cold water is poured over my head. 'Keep praying' he snaps, not even giving me a chance to recover from the surprise drenching. My Catholic prayers must help enable the Candomble cleansing taking place here today, as I bring my own spirituality to this rather alien setting.

[1 $1^{\text {st }}$ author fieldnotes, July 2017, Salvador, Bahia]

The opening vignette illustrates several noteworthy aspects of Brazil's religious marketplace. Firstly, it demonstrates a certain accessibility, meaning that collective and/or individual religious services are being offered to consumers in search of some form of healing regardless of their faith. Rather than clearly demarcating the boundaries of their religion, some places of worship welcome practitioners from other faiths. Secondly, the vignette shows how seemingly competing religions (if we consider them to compete with one another for adherents, see Einstein, 2007) can in fact complement each other in their offerings. Rather than negating the religious knowhow and abilities of adherents that come from other religions, we see how places of worship utilise this knowledge and expertise to their benefit, by encouraging religious mobility and thereby ensuring a plentiful stream of consumers. This study therefore focuses on how consumers use their religious knowhow (or accrued religious capital) to move across the religious marketplace often even consuming multiple religions in parallel; and how this 
multifarious religious consumption is not only expected, but at times encouraged, by religious leaders themselves.

Steil (2001, p.120) has defined religious transit as "the movement of the religious actors through various sacred spaces and/or religious beliefs and the simultaneous practice of different religions" (see also Almeida, 2004). Although previous research has explored how consumers seek personal spiritual journeys in an effort to bring meaning to their lives, picking and mixing from a variety of spiritual offerings (see Roof, 1999; Houtman \& Aupers, 2007; Redden, 2016), our study moves beyond the New Age spiritual context to examine consumers who not only freely transit between competing religions but also consume them in parallel. In so doing we answer our research question. How does religious capital make it possible to simultaneously practice multiple religions and navigate tensions between theologically incompatible beliefs in a complex religious marketplace?

To demonstrate how this religious transit is made possible, we build on theories of religious capital, foregrounding the flexibility of this resource which is accrued by consumers throughout their religious journeys. We define religious capital as an individual's ability to produce and appreciate diverse religious commodities (tangible and intangible). This capital is accumulated both from the habitus received from their upbringing and from the time and labour they have subsequently devoted to varied religious activities, sometimes, as we will show, through participation in the religious marketplace. Following Bourdieu (1986) this capital can be accumulated and transferred from one religion to another. By focusing on religious capital we demonstrate how religious mobility can be an advantage for both religious consumers and institutions. Unlike previous studies which tend to focus on religious conversion, assuming the exiting of one faith to enter another and the negating of previous beliefs (Iannaccone, 1990; Stark \& Finke, 2000), we show how consumers build up multifarious knowledge, abilities, tastes and credentials (non-monetary assets) from various religions (Verter, 2003). In this 
sense, faith is not a static state of affairs but rather is continually achieved.

There have been two streams of research examining religious capital, the first is positioned within economic rational choice and the second comes from Bourdieu and his sociological studies of capital. While these two bodies of literature differ significantly, they both assume that a religious consumer can only consume one faith at a time. According to economic rational choice theories, religious (human) capital (RHC) is understood as the knowledge and familiarity with church ritual and doctrine that provides adherents with tangible benefits within a single church setting (Iannaccone, 1990; Stark \& Finke, 2000). Thus, higher levels of religious human capital implies an increase in participation at a particular church, and therefore diminished likelihood of denominational mobility (Iannaccone, 1990; Corcoran, 2012). Moving from one religion to another, according to the RHC premise, would imply a loss for the consumer as their religious knowhow and status are not easily transferable, so that they will be required to invest in the new religion in order to gain any benefits from it. We see this illustrated in McAlexander, Dufault, Martin and Schouten's (2014) study of disaffected members of the Mormon Church, who, at the moment of leaving the institution, lose social relations and field-dependent capital and are therefore forced to rebuild their selfunderstandings and accrue new capital in an unfamiliar field, such as the marketplace (see also Arsel \& Thompson, 2011 on the 'stickiness' of field-dependent capital). Although the premise of rational choice theory has been offered as an explanation of the rise of conservative churches (Iannaconne, 1994), it does little to account for the mobility of today's religious consumers. By examining consumers who are actively mobile, following several religions in parallel, we show that Iannaconne's premise is not always correct. Rather, religious capital, within a flexible and receptive religious marketplace, can enable consumers to navigate between seemingly theologically incompatible beliefs if these beliefs share certain discourses and rituals. We therefore turn to Bourdieu's (1991) notion of religious capital for an alternative 
perspective.

Bourdieu (1991) argued that religious capital was both produced and accumulated within a particular institutional framework (church denomination), meaning that religious capital was limited to those who produce religious outputs (i.e. leaders of a church) who then shape the religious habitus for others (i.e. laypeople) through their symbolic ideologies and competences, ensuring legitimisation and authority for the church. However, Verter (2003) has demonstrated how Bourdieu's later research on cultural capital can further his relatively limited notion of religious capital by going beyond simply focusing on religious leaders. In this sense, the accrued knowledge, abilities, tastes, and credentials of a faith are thought to provide adherents or laypeople with competitive advantages in the symbolic economy. Verter (2003, p.158) differentiates this form of capital by noting that it is flexible in nature as it is "governed by more complex patterns of production, distribution, exchange, and consumption." Underpinned by the sociological notions of capital, this definition helps further our understanding of religious consumption in our research setting, as it is a "model characterised not by stasis, but by change" (Verter, 2003, p.170).

While previous research has shown how spiritual consumers are increasingly seeking to mix and match beliefs and practices from a variety of faiths and spiritualities (e.g. the spiritual supermarket literature, see Roof, 1999) and has evidenced the increasingly sophisticated marketing practices currently adopted by religious institutions to compete for market penetration (Einstein, 2007, 2013; Miller, 2004; Twitchell, 2005, 2007), we demonstrate how contemporary religious consumers navigate this vast set of marketplace offerings to weave a coherent religious identity amongst seemingly theologically incompatible discourses. Understanding this religious transit necessitates an understanding of how religious consumers gain religious capital through their participation in the religious marketplace whereby shared discourses and rituals make the various offerings comprehensible and 
accessible. In their transiting between faiths and accrual of religious capital, we notice how some religious consumers actively syncretise multifarious religious offerings, thereby crafting a uniquely layered religious identity for themselves. Our analysis therefore presents an interesting 'third form' of religious consumption, situated between the 'strict churches' of Iannaccone (1994) and the more personal quest of the spiritual supermarkets (Roof, 1999), whereby religious consumers still privilege religious doctrines over personal experience but do so across various religions. Moreover, these increasingly market-oriented religions accept and, at times, encourage, this mobile religious consumption.

By locating our study in the context of Brazil, we respond to Richelieu and Korai's (2012) call for further research on religious consumption in emerging economies (other notable studies include Hackley and Hackley (2016) on Thailand, Eckhardt and Mahi (2012) on India, and Bonsu and Belk (2003, 2010) on Ghana). As well as being renowned for its rich religious syncretism (the mixing of elements of different religions and spiritual practices in the creation of a new belief system), Brazil is notable for the mobility of its religious consumers, where one in three people have changed religion, many choosing to participate in several faiths in parallel (Almeida, 2004, 2006; Almeida \& Monteiro, 2001). Through interviews with religious consumers and some religious leaders of four faiths: Pentecostal, Spiritism, Candomblé, and Umbanda, coupled with fieldwork at each of these churches, we examine the 'religious transit' of Brazilian consumers. This allows us to develop a typology of four types of consumer mobility, namely tourist consumers, migrant consumers, sojourner consumers and shuttle consumers. By differentiating between the dynamics and characteristics of these religious transits, to examine how consumers utilise - to differing degrees - their accrued religious capital to move around the religious marketplace, we better understand how these consumers can move between seemingly competing religions. 


\section{The Marketisation of Religion and Postmodern Spiritual Supermarkets}

With over $80 \%$ of the world's population practicing a faith, the topic of religion is a central one in consumer behavior (Pew Forum, 2012). The interface between religion and consumption has been well researched (Mittlestaedt, 2002; Maclaran et al., 2012) with notable studies focusing on: the globalisation strategies of churches (Twitchell, 2005; Miller, 2002; Robbins, 2004); the influence of religion on consumer behavior (Hirschman, 1981; IzberkBilgin, 2012; Üstüner \& Holt, 2007) and the effects of religion on consumer psychology (Mathras, Cohen, Mandel \& Mick, 2016); the wealth of the gospel and propagation of materialism (Bonsu \& Belk, 2010; Yip \& Ainsworth, 2016); the interface between macromarketing and religion (Kale, 2004; Benton, 2016; Drenten \& McManus, 2016); the sacralisation of consumer culture (Belk, Wallendorf, \& Sherry, 1989; Atkin, 2004; Belk \& Tumbat, 2005; Muñiz and Schau, 2005; Fernandez and Lastovicka, 2011) and the sacralisation of consumer experiences (Belk \& Costa, 1998; Sherry \& Kozinets, 2007; St James, Handleman \& Taylor, 2011); the socialising role of religious consumer identity (McAlexander et al., 2014) as well as other studies which highlight the marketisation of religion more generally (e.g. Cimino \& Lattin, 1999; Crockett \& Davis, 2016; Einstein, 2007, 2013; Shirazi, 2016; Moore, 1994; O’Guinn \& Belk, 1989; Rinallo, Borghini, Bamossy \& Kozinets, 2013; Twitchell, 2005, 2007).

Amidst this wealth of research into the complexities of religious consumption, we can define religion as "systems of meaning embodied in a pattern of life, a community of faith, and a worldview that articulate a view of the sacred and of what ultimately matters" (Mathras et al., 2016, p.300). No longer benefiting from the monopolistic role they once enjoyed (McAlexander et al., 2014; Rinallo, Maclaran \& Stevens, 2016; O’Guinn \& Belk, 1989), religions today compete for 'consumers' who seek systems of meaning that best suit their lifestyles on the open market, just like in any other industry (Berger, 1967). In line with this 
market-mediated logic, we understand how "spiritual needs translate into demand for goods and services" (Kale, 2004, p.92), so that religious organisations become embedded in a logic of market economics (Finke \& Stark, 1988), where they can be consumed, branded, and marketed. No longer immune to market forces, religious institutions today must therefore compete with one another as each offers a more credible, personalised and attractive package to the potential consumer (see Miller 2004; Einstein 2007; Moore 1994; Roof 1999; Twitchell 2005).

In line with these studies, in his book Spiritual Marketplace, Roof (1999) argues that consumers 'seek' personal religious interests in a more open and flexible biographical spiritual quest, no longer bound to a socially-ascribed religious tradition. With the fall of monopolistic religions in the West, consumers are able to construct personal packages of meaning "based on individual tastes and preferences" (Aupers \& Houtman, 2006, p.201), meaning that the postmodern spiritual consumer moves away from external authorities towards "the autonomy, empowerment and authority of 'spiritual seekers,' whose spirituality is located from within" (Rinallo, et al., 2016, p.427). Unlike organised religion, spirituality can be defined as an inner state of being where the consumer searches for self-transcendence, the sacred, a purpose in life and place within the universe (Knoblauch, 2008; Schneiders, 1989), or a "personal belief system" (Myers, 1990, p.11). Kale (2004: 304) explains how spirituality is perceived "as the more personalised aspect of faith whereas religion is perceived as the more formalised and institutionalised manifestation of faith." This pursuit of a personal belief system is part of a larger shift away from the authority of institutionalised religions towards increased individual freedom (Firat, Dholakia \& Venkatesh, 1995) to create beliefs from a variety of competing (or complementary) spiritual resources from divination to yoga (Altglas, 2014).

Under this premise of the spiritual supermarket, consumers select from various forms of spirituality to build up their own "biographical spiritual quest" (Redden, 2016, p.231). While 
this emphasis on consumer choice has been established in relation to New Age beliefs (Bowman, 1999; Urban, 2000; Mulcock, 2001), it has generally been denigrated in the literature due to an unease with applying a commercial market logic to the spiritual. However, this more individualistic and instrumental do-it-yourself approach to the spiritual is reflective of a neoliberal ideology of self-sufficiency through market choice, whereby "market-governed freedom of choice provides a framework for projects of self' (Redden, 2016, p.238; Giddens, 1990; Aupers \& Houtman, 2006). New Agers are known to "move between spiritual and quasispiritual alternative lifestyle options often combining several during any period of their own spiritual journey” (Redden, 2016, p.233) creating a 'self-spirituality' (Heelas, 1996). By mixing and matching multiple traditions, styles and ideas simultaneously, postmodern religious consumers create idiosyncratic, personal packages.

Our study extends this line of literature by going beyond the New Age spiritual context. While we also examine personal belief systems, our focus is on how this spiritual 'pick and mix' approach has been applied not just to spiritual practices but to institutionalised religions. As such, the religious consumers we study, are not picking distinct elements from various idiosyncratic spiritual packages but rather, are moving between different formalised religions, becoming adherents to the doctrines of multiple faiths at once.

\section{Religious Capital and Market-mediated Religious Transits}

As noted in the introduction, the notion of religious (human) capital emerges from Religious Economic Theory, where individuals are thought to make religious choices based on rational choice (Iannaconne, 1990; Starke \& Finke, 2000), meaning that adherents of a faith choose a denomination that maximises their returns taking into account the time, effort and financial investment made to the institution (i.e. church) (Corcoran, 2012). Conceptualising religious practice as 'capital' furthers our understanding on what is being acquired and 
accumulated by the religious consumer (Finke, 2003). Stark and Finke (2000, p.120) note how religious capital is the "mastery of and attachment to a particular religious culture." Finke (2003, p. 3) elaborates further on the religious investment that builds up over time:

to fully appreciate a religion requires emotional attachments and experiences that become intrinsic to one's biography. Religious activities such as prayers, rituals, miracles, and mystical experiences, build up over a lifetime, not only increasing confidence in the truth of a religion, but strengthening emotional ties to a specific religion.

In his seminal paper on the subject, Iannaconne (1990, p.299) defines religious capital as "the skills and experience specific to one's religion includ[ing] religious knowledge, familiarity with church ritual and doctrine, and friendships with fellow worshippers [who help one] produce and appreciate religious commodities." Thus, the knowledge, familiarity, and networks created within a specific religion help the faithful enhance their religious satisfaction (Finke, 2003). Religious participation, Iannaconne (1990, p.299) continues, "is the single most important means of augmenting one's stock of religious human capital," meaning that it would be "difficult if not impossible to appreciate religious services without first becoming familiar with the doctrines, rituals, and traditions that underpin them." It therefore follows that people will do their best to conserve their religious capital and stay faithful to their religion. As individuals master their religion and intensify their emotional attachments to it, the less likely they will be to convert as that would mean losing their investment (Stark \& Finke, 2000). We see this clearly in McAlexander et al.'s (2014) study of ex-Mormons who suffer immensely at the loss of their field-specific capital within their religious context.

However, critiques of rational choice models of religion point out the underlying assumption (borrowed from neoclassical economics) that people are just free to choose and pursue their preferences in the marketplace of beliefs is simplistic (Bruce, 2014). As the consumer culture literature makes clear, religious actions of individual persons are shaped by social influences which are not necessarily rational i.e. based on the maximisation of benefits. 
It is therefore useful to consider an alternative view. In our use of religious capital we look towards Verter (2003, p.170), who in turn builds on Bourdieu (1986), whereby:

individual investment [is] not a steady accumulation along a linear path, but rather [is characterised as] an incessant recalculation of one's position within a framework of human relations - a framework modeled not simply by one's family or one's church, but by one's broader social field."

This definition more readily explains a religious consumption in which various institutionalised faiths are practiced in parallel.

Verter further specifies three forms of religious capital, mirroring Bourdieu's (1986) forms of cultural capital, namely the embodied state, the objectified state and the institutionalised state. The embodied state encapsulates the "knowledge, abilities, tastes, and credentials an individual has amassed in the field" through education or unconscious socialisation (Verter, 2003, p.159). Our findings reveal how the religious consumer is able to utilise this accrued knowledge, ability, taste and expertise in moving from one faith to another. The objectified state focuses on the material and symbolic commodities of these faiths, in knowing how to use sacred objects correctly, adherents can correctly consume various faiths, thus enhancing satisfaction in participating in that religion. What we find is that religious organisations foreground this symbolic materiality as a way of making their faiths more accessible to adherents from other faiths. Lastly, the institutionalised state includes the power of churches and other religious organisations to legitimise their field. Here, religious leaders play an important role in facilitating religious transits between faiths.

As churches compete with one another for adherents, playing by the rules of the market economy, denominations that are able to attract and retain congregants may be more popular and successful in this highly competitive field. Following a rational choice logic and building on Kelley's (1986) research on declining church attendance in the USA, Iannaconne (1994) argues that more conservative denominations will be more effective at maintaining high levels 
of participation, so that ecclesiastical strictness (including and rigid adherence to a distinctive lifestyle) will reduce the 'free riding' behaviour of the congregation. Although some conservative denominations may do well in retaining their faithful (for instance Mormonism, as mentioned earlier), others may in fact take the strictness one step too far and intimidate adherents, which can be seen in the rise and fall of many religious denominations and/or cults. Nevertheless, as followers of strict churches devote more time and money to their religions, they are more likely to describe themselves as strong members of that (single) faith, following a religious human capital logic (Iannaccone, 1990; Stark \& Finke, 2000).

However, in direct opposition to this thesis, it is not only conservative churches that are able to attract congregants. Whilst strict churches proclaim an exclusive truth and closed doctrine, a new wave of churches reveal an ecclesiastical openness that is appealing to the contemporary consumer in search of a customised belief system. Duarte (2001) argues that the contemporary consumer can in fact move around several religions in tandem and adopt diverse meanings from each of these faiths according to their particular needs, in what Brandão (1994, p.34) referred to as the "religious market situation" whereby polysemous religious experience becomes the norm. Rather than simple conversion, we see a 'religious transit' which does not deny the previous religion and life of the adherent and does not demand their rigid commitment (Almeida, 2004). Religious transit, i.e. the movement between and simultaneous practice of various religions, is therefore "less defined and more processual, signalling continual change rather than largely stable and exclusive religious identities" (Amoruso, 2018, p.7). This movement, contrary to Iannaccone's data, is at times relatively effortless and viewed as complementary, where consumers evince a guilt-free and easy mixing and matching of multiple religions (Duarte, 2001) despite the seeming incompatibility of the various belief systems. A more nuanced perspective is therefore required to understand how the faithful are able to transit across the religious marketplace at differing degrees of commitment and 
frequency. These consumers are able to navigate tensions between the various places of worship thanks to the accruement of religious capital that is, the knowledge, ability, taste and expertise amassed in the field.

In order to answer our research question: how does religious capital make it possible to simultaneously practice multiple religions and navigate tensions between theologically incompatible beliefs in a complex religious marketplace? we focus on the Brazilian context. We do so as this is where the notion of a religious transit, that is, the movement of individuals between different faiths, emerged from (Almeida \& Monteiro, 2001).

\section{Context: Brazil's religious marketplace}

The case of Brazil is particularly illuminating for our analysis of religious transits, given that ninety per cent of the population declare some religious affiliation and one in three have changed faith at least once (Almeida, 2004; 2009). The faithful in Brazil do not feel bound to the religion that they inherit (usually Catholicism), but rather feel a freedom to move around the various religious options available in an exploratory manner. Sanchis (2001, p.25) argues that the religious style that crystalised in Brazil from the early colonial period onwards was characterised by a "structural predisposition to porosity." This paper explores the reasons behind this religious transit and unpacks how this journey is possible through the accumulation of religious capital. To do so, we examine four popular faiths in Brazil: Pentecostalism (with a focus on the fastest growing and most influential church in the country, the IURD, Igreja Universal do Reino de Deus), Spiritism, and Afro-Brazilian religions, namely syncretised Candomblé and locally developed Umbanda. For further details on the specific faiths please see Appendix A. As the most populous city in Brazil, São Paulo is particularly diverse in terms of faiths and cultures, providing its inhabitants significant potential mobility in their religious transit and is therefore the focus for this study. 


\section{Methodology: Mapping the religious transit}

We follow previous consumer research (Arnould, Price \& Otnes, 1999; Belk et al., 1989; Scott \& Maclaren, 2013) in adopting an interpretive ethnographic methodology, which allows for the most detailed "study and representation of culture" (Van Maanen, 1988, p.150). The first author lived in São Paulo for the duration of the study, allowing for an immersive ethnography where she could 'go native' in the field, which is both common and even beneficial in the study of religions (McCutcheon, 1999). By experiencing the various faiths in the same manner as locals (Schouten \& McAlexander, 1995), she became more culturally informed about the religions under study and also more aware of the socio-political sensitivities of the field (Rinallo et al., 2016). The second author visited for more intensive 'bursts' of data collection, allowing for alternative perspectives, and further bridging the insider-outsider gap. Through this multi-participant observation, we were able to triangulate our findings and generate rich fieldnotes (Peñaloza \& Cayla, 2006), which amounted to just over 250 pages plus 656 videos and photographs. In line with Van Maanen's (2011) ethnographic tasks, the authorial team conducted fieldwork, headwork and textwork, as a means of observing, thinking, and writing about the field under study.

During this fieldwork, the authorial team took part in weekly religious services across the four faiths as well as specific rituals, as a way to "soak up [the] data" (Mason, 2002, p.90). This included divinations, consultations with mediums and the oracle (most notably resulting in an offering to Ogum, the Orixá (deity) of war, so that he would help open up our paths to successful academic publications, see Appendix B), as well as spiritual cleansing rituals (including the one in our opening vignette). During church services as well as during personalised consultations, the authorial team took on the role of religious consumers, actively participating in healing on offer in this market-mediated religious landscape. 
Given the symbolic complexity of our study, where a multifarious syncretism has shaped Brazil's religious panorama, it was important for members of the research team to be sufficiently familiar (professionally as well as personally) with the religions under study, as a means of "navigat[ing] the context" (Crockett \& Davis, 2016, p.214). This prior understanding helped "sharpen" (Gould, 2006, p.77) our research analysis through familiarity at the emic level (for further information on the authors' viewpoints see Appendix C).

Data collection was carried out between March 2016 and July 2017. In addition to the fieldnotes from our ethnographic research, a total of seventeen semi-structured depth interviews were conducted, lasting from 30 minutes to three hours (see Table 1 for details). The interviews allowed us to gather religious consumers' perspectives on their religious transits. Interviews were carried out by the authors in participants' native Portuguese and were digitally audio-recorded and professionally transcribed verbatim. These transcripts, which amounted to just over 450 pages, were then translated by the first author, who is fluent in English and Portuguese, and shared with the second author for collective data analysis. The sample included males and females ranging from their 20 s to 60 s and representing various socio-economic classes. Notably, all the participants had self-identified as being adherents of at least two faiths, most of which were in parallel, this means they do not just participate in the rituals from time to time but rather consider themselves to actively practice those faiths (see Table 1 for an overview of participants religious transits). Recruitment and access were gained through the first author's immersion in the field. Once a shared language and understanding of the various faiths was achieved, essential 'gatekeepers' (McCracken, 1988) such as priests and initiates led to further recruits through a snowballing procedure. In line with research ethics standards, all participants were given consent forms to read and sign and all personal details were made anonymous. 
Table 1: Research participants and their religious transits

\begin{tabular}{|c|c|c|c|}
\hline Pseudonym & Demographics & Consumer Typology & Religious Transit \\
\hline Graziela & $\begin{array}{l}\text { Female, mid 50s, domestic services, high school } \\
\text { education }\end{array}$ & Migrant & Catholicism $\rightarrow$ Pentecostalism \\
\hline Guilherme & $\begin{array}{l}\text { Male, early } 40 \text { s, professional, university graduate, } \\
\text { works in museum field }\end{array}$ & Migrant & Catholicism $\rightarrow$ Pentecostalism \\
\hline Fernando & Male, mid 20s, university graduate, professional & Migrant & Spiritism $\rightarrow$ Umbanda \\
\hline Teodoro & $\begin{array}{l}\text { Male, mid 30s, university graduate, full time } \\
\text { Candomblé priest }\end{array}$ & Migrant & Umbanda $\rightarrow$ Candomblé \\
\hline Anderson & Male, early 40 s, university graduate, professional & Migrant & Catholicism $\rightarrow$ Spiritism \\
\hline Carola & Female, mid 40s, university graduate, house-wife & Tourist & Catholicism $\bullet \bullet$ Spiritism \\
\hline Thiago & Male, mid 20s, university graduate, professional & Sojourner then Migrant & Catholic $\approx$ Spiritism $\approx$ Umbanda $\rightarrow$ Candomblé \\
\hline Leonora & $\begin{array}{l}\text { Female, mid 30s, postgraduate education, } \\
\text { professional }\end{array}$ & Sojourner then Migrant & Catholic $\approx$ Umbanda $\rightarrow$ Candomblé \\
\hline Janette & Female, mid 20s, college student & Sojourner then Shuttle & Catholicism $\approx$ Pentecostalism $\approx$ Umbanda $\approx$ Spiritism $\Leftrightarrow \Rightarrow$ Catholicism \\
\hline Marisol & $\begin{array}{l}\text { Female, mid 40s, migrant worker, domestic } \\
\text { services, high school education }\end{array}$ & Shuttle & Catholicism $<=>$ Pentecostalism \\
\hline Paola & Female, early 40 s, doctoral student, professional & Shuttle & Catholicism $<=>$ Spiritism \\
\hline Regina & $\begin{array}{l}\text { Female, mid 30s, university graduate, self- } \\
\text { employed (store owner) }\end{array}$ & Shuttle & Catholicism $<\Rightarrow$ Umbanda $<=>$ Candomblé \\
\hline Cassia & $\begin{array}{l}\text { Female, late } 30 \text { s, university graduate, } \\
\text { journalist/blogger }\end{array}$ & Shuttle & Catholicism $\Leftrightarrow=>$ Umbanda $\Leftrightarrow>$ Candomblé \\
\hline Arturo & $\begin{array}{l}\text { Male, early } 50 \text { s, vocational training, Umbanda } \\
\text { priest and part-time tradesperson }\end{array}$ & Shuttle then Migrant & Catholicism $\Leftrightarrow=>$ Spiritism $\rightarrow$ Umbanda \\
\hline Clemência & $\begin{array}{l}\text { Female late } 40 \text { s, some college, former bank clerk, } \\
\text { now beautician }\end{array}$ & Shuttle + Tourist & Catholicism $<=>$ Umbanda $<=>$ Candomblé $\cdots$ Pentecostalism \\
\hline Raiza & $\begin{array}{l}\text { Female, early } 60 \mathrm{~s} \text {, university graduate, retired bank } \\
\text { employee }\end{array}$ & Shuttle + Tourist & Catholicism $<\Rightarrow$ Umbanda $\cdots$ Candomblé \\
\hline Iandara & $\begin{array}{l}\text { Female, mid 30s, university graduate, self- } \\
\text { employed (store owner) }\end{array}$ & Shuttle + Tourist & Catholicism $<=>$ Umbanda $\bullet • •$ Candomblé \\
\hline
\end{tabular}

\footnotetext{
Key

$\rightarrow$ Migrant consumer

.. Tourist consumer

$\approx$ Sojourner consumer
} 
« Shuttle consumer 
As a means of capturing our participants' religious transits across various faiths, we included a visual stimulus during the interview process (see Appendix D). Adapted from Almeida (2004), this diagram allowed our participants to actively chart their religious journey, generating rich data to complement interviews. Using a visual stimulus helps "foreground and objectify aspects of the respondents' experience" which may well be overlooked in an oral interview alone (McCracken, 1988, p.37). By tracing their movements between faiths, participants were able to delve deeper into when, how and why they transitioned between religions, providing a more nuanced account of their movement between faiths and how these faiths complemented each other. Maps set cognitive boundaries and therefore examining how participants mapped their own religious trajectory provided valuable insight into their movements, depicting participants' ongoing personal religious narrative as a meaning-making process.

Our study adopted an iterative and hermeneutic approach to analysing the various sources of data collected by the research team (Arnold \& Fischer, 1994; Thompson, 1997) to ensure a free and enriching flow between our fieldwork, emerging themes, and pertinent literature. Although saturation was achieved from our ethnographic fieldnotes and our interviews, our data was further supplemented with secondary data from other disciplines, namely work in sociology and anthropology of religion by Brazilian scholars, some of whom we consulted in person in order to further inform our understanding of these faiths and triangulate our own findings. Due to the sheer amount of data collected and the exploratory nature of the paper, we focus on a sample of our respondents to better illustrate the religious transits taking place.

\section{Findings: Towards a Typology of Transiting Religious Consumers}

\section{Enabling Transits: Institutionalised religious capital}


Our data reveals a significant mobility across religions amongst consumers in Brazil. These religious transits are made possible through varying levels and types of religious capital, as we will show, but would not be possible without significant institutionalised capital which characterises Brazil's religious panorama. This is why it is perfectly acceptable for Brazilians to admit to following various faiths at once, the religious institutions recognise and make use of their consumers' religious capital accrued from other faiths (as evidenced in the opening vignette), thereby enabling their religious transits. Indeed, many of the religious leaders have experienced religious transits themselves.

For example, the church founder of the IURD, Bishop Edir Macedo, was raised in Umbanda before converting to Pentecostalism as a young adult. As well as referring to his own Umbanda background regularly and openly during church services and interviews, Macedo has also published a book where he explains the rituals of Afro-Brazilian churches. Although the IURD warns its adherents of the dangers of other faiths such as the Afro-Brazilian religions, it does not negate consumers' accrued knowledge and expertise. Rather, it makes purposeful use of this capital through the appropriation of ritual objects and procedures from Afro-Brazilian churches. This is widely acknowledged as a salient feature of the IURD's strategy of expansion (Rabelo 2015). Other religious leaders not only acknowledge but encourage adherents to frequent other places of worship in parallel, as a means of complementing their religious experience. For example, Paola was encouraged by the Spiritist religious leaders ${ }^{1}$ to frequent the Catholic Church on a weekly basis, whilst still practising Spiritism and receiving the ongoing healing on offer there:

Although I was raised Catholic, I had fallen out of the habit of going to [the Catholic] church. But when I started this spiritual treatment, and started going to the Spiritist centre on a regular basis, they [church leaders] told me to take my family to the

\footnotetext{
${ }^{1}$ It is worth noting that the founder of Spritism, Allan Kardec was a Catholic himself, and his writings therefore reflect this (The Gospel according to Spiritism (1864), Heaven and Hell (1865) and Genesis (1868)).
} 
Catholic church on Sundays... that it would help us ... it would help with the spiritual healing.

Similarly, Arturo, an Umbanda priest was raised within both Spiritism and Catholicism, before turning to Umbanda as a teenager, and later becoming a church leader. As such, he accepts the transient quality of some of his congregants:

We have no intention of converting people, many people just come in search of help from the entities [spirits incorporated into human hosts] and once they have received this help, they go away and only come back when more guidance is needed.

He even mentions seeing Pentecostal and Evangelical congregants and pastors at his Umbanda temple, who have come in search of the consultancy services from mediums. In this sense, consumers are free to come and go as they wish. Unlike in Iannaccone's (1994) strict churches, we see a relaxing of boundaries. This does not mean the religions are not differentiated, but rather that they can be characterised by consumers as complementary rather than simply competitive due to this institutionalised capital. In order to understand how consumers move around a religious marketplace, it is therefore necessary to further understand how they use their religious capital to negotiate between any tensions between competing religions.

\section{Transiting Consumers: Embodied and objectified religious capital}

We conceptualise the way consumers move across the religious landscape by classifying them into four categories, namely: migrant consumers, tourist consumers, sojourner consumers, and shuttle consumers.

\section{Religious consumers as tourists}

Unlike previous studies on religious tourism (Prayag, Mura, Hall \& Fontaine, 2015; Winkelman, 2005; Husemann \& Eckhardt, 2018), where tourists are often non-practicing consumers who travel to sacred sites to experience spiritual healing, as we see in Ayahuasca 
tourism for instance, the religious consumers in our study demonstrate a tourism of other religions in parallel to their own faith. That is, when religious consumers are searching for life solutions, they will try out various options available in the marketplace. Some consumers may be looking for religious guidance, but many are searching for celestial solutions for their earthly problems, including issues with finances, work, love, health, or any other personal problem. According to Corten, Dozon and Oro (2003), this is typical of postmodern religious consumption: to be successful, churches in Brazil need to acknowledge the day-to-day trials and tribulations of their adherents, providing them with the institutionalised capital necessary to find solutions in their particular faith. With little previous knowledge of the faiths, tourists can therefore dip in and out of various faiths.

Health, as essential to life, is therefore a topic, which came up repeatedly in our interviews. At the intersection of religion and medicine, Spiritism offers the consumer an attractive pseudo-scientific theology including simulated doctor surgeries and faux, noninvasive surgeries. Carola, a devout Catholic, was encouraged by a friend to visit one such Spiritist clinic in the interior of São Paulo state for her labyrinthitis after conventional medicine failed to cure her.

I had been to see all sorts of doctors and specialists and things were just not getting any better... so a friend of mine who is a Spiritist invited me to this clinic where a 'doctor' performs a surgery on you. I am Catholic so I was anxious about going to the Spiritist clinic but I was desperate... nothing was working.

Despite her anxiety, Carola's nerves were somewhat eased once entering the Clinic, when she saw familiar Christian imagery.

At the entrance to the clinic there was a large mural of what looked liked the Virgin Mary but she was dressed all in white rather than her usual robes. Inside [the operating theatre] there was also an image of Christ but no crucifix. These pictures provided me with some comfort.

As well as Christian-like imagery, visitors to the Spiritist clinic are invited to bring their 
religious amulets and icons from home. Moreover, in preparation for the surgery, visitors are told to pray - Carola notices how the people around her revert back to their anchor faith, despite being in this alien setting:

I hear people around me praying the Our Father or Hail Mary quietly, like a mantra, clutching small statuettes of the Virgin or Jesus in their hands... I brought my Virgin icon with me and started praying. I was pretty nervous before the surgery... this helped calm my nerves.

Spiritism, like all the religions studied in the paper, therefore acknowledges consumers' existing objectified and embodied religious capital. This makes the new religious experience all the more relatable.

After the surgical-spiritual intervention, Carola was 'hospitalised' for two days to 'recover' from the surgery. Although she felt that the surgery had a positive effect on her wellbeing, she carried some guilt with her about attending the Spiritist Clinic and commented on how she went to Confession at her local church to ensure a clear conscience.

When I got back to São Paulo, that Sunday I went to speak to my priest... I needed to tell him about my experience, although I felt better, it was weighing on my conscience that I had been to this clinic. He was really understanding and he reassured me that this didn't affect my connection with God, you know, it didn't make me less Catholic.

This form of consumer mobility is therefore not dissimilar to conventional notions of the spiritual supermarket. Tourists try solutions provided by alternative faiths, testing them out when and as required but do not commit and continue to show loyalty to their 'core' religion (in Carola's case, Catholicism). Consumption of tourists tends to be ephemeral and short-lived. This type of consumer mobility, therefore, requires minimal spiritual capital on the part of consumers - only superficial levels of objectified capital (in terms of familiar iconography) and embodied capital (in terms of familiar rituals). These are therefore built into the religious marketplace's customised services, as well as Spiritist surgeries, we see similar purposeful 'interventions' in Afro-Brazilian religions, with Umbanda or Candomblé consultations (which provide recipes for offerings - see authors' example of an offering in Appendix B - or cleansing 
baths), and tailored services at the IURD which cater to consumers looking for quick-fix solutions.

\section{Religious consumers as migrants}

By consumers as migrants we mean those who move in a permanent fashion from one religion to another, meaning that they convert from one faith to a new one. This is therefore the most straightforward form of religious transit, the consumer moves from one faith that is no longer deemed satisfactory in offering solutions for life's problems, to a new one. Conversion, is of course, not a new phenomenon and as such has been covered in the literature. However, in examining the various forms of religious mobility, we can see how these are different in kind rather than nature. So, for example, consumers may start their transit as tourists, for instance testing the new religion, or different denominations of that same religion, before then deciding to migrate to the new faith.

Much as with Carola, Guilherme explores Spiritism, in the first instance, for a medical reason.

I started going Spiritist services because I had some terrible head pain. First, I had been to the doctor, to a neurologist, especially since my mother had had brain cancer. I had some tests done and they found a shadow on my brain. And nobody knew what that shadow was. So, I went to the Spiritist clinic to get another opinion and started a 16-week treatment with the Spiritist clinic, with 'passés' (magnetic healing), fluidified water and chromotherapy (light therapy). [After several months] I had new tests done and nothing ... I had nothing. As if I had never had anything at all. I know this sounds like crazy talk.

By tapping into the healing powers of the spirit world, Guilherme found the solutions to his physiological and spiritual problems in Spiritism. He coupled his pseudo-medical treatment at the Spiritist Clinic, where faux-surgeries and other treatments are offered, with regular Spiritist attendance at his local Spiritist centre, which acts much like a church. In this migration, 
Guilherme was not required to eradicate all notions of his Catholicism, and therefore negate any accrued religious capital, but rather was able to reframe his Catholic narratives in line with the cosmology of the Spiritist doctrine (where there is already some institutionalised capital in that Jesus is considered a spiritual guide).

I was raised in an extremely Catholic family, I know all the Saints, and all the religious doctrines of Catholicism. However, once I started attending Spiritist services, I realised that this Gospel made more sense to me, it explained so many things which I had previously had no explanation for... I remember as a child feeling the presence of my grandparents after they had died and Spiritism tells us how our bodies are mortal but spirits are eternal and are reincarnated over and over again, becoming more enlightened with each reincarnation. Our spirits, like divine sparks, are forever present on Earth.

The Spiritist Gospel therefore builds upon Guilherme's pre-existing knowledge of Catholicism, offering a more meaningful religious outlook, allowing for spiritual enlightenment. Guilherme feels so strongly about his conversion that he now volunteers at his local Spiritist Centre and teaches the youth group about the Gospel according to Spiritism. This has provided with a sense of belonging and community which he previously lacked, allowing for selftransformation.

Migration, as a more committed transit than that seen in tourism, therefore demands a deeper engagement on the part of consumers with their embodied capital (particularly in terms of religious doctrine). It requires active effort on the part of the consumer to reframe this embodied capital so that it can be used as a base on which further, new, religious knowledge can be built. In this way, existing embodied capital provides an entry into the new religion, made possible through the institutional capital. Therefore, in the case of migrants, objectified capital is of lesser importance as they have already noticed a certain level in their initial contact with the new faith (i.e. as tourists). 
Originating from the French 'sojorner,' to stay or rest, a sojourner refers to a person that resides in a place temporarily for work and/or education purposes (Gullekson \& Vancouver, 2010), without actual intentions of permanent migration. Unlike tourists, who only pass through only fleetingly, and migrants who settle permanently, sojourners stay long enough to have an impact in their host location (Liu \& Shaffer, 2005) and to amass new experiences, knowledge, acculturation capabilities, social connections, and skills from their host location (Tung, 1998). In our context of religious transit, we define sojourners as those consumers that remain in a given religion for an extended period time before moving onto a new religion or an alternative form of transit.

Whereas Guilherme successfully reframed his embodied religious capital in order to convert to Spiritualism, Janette ultimately failed to do so. Although she progressed beyond tourism, her participation in both Pentecostalism and Umbanda, although committed and lasting several years, was ultimately transient. Janette's religious transit is illustrated in Appendix C, she first transited from her inherited Catholicism to the IURD, where she was fully immersed in the religion for several years, before moving onto Umbanda. After these temporary relocations, Janette's religious transit shifted to a shuttle pattern, which we explore in the next section. Ultimately, in both Pentecostalism and Umbanda Janette found elements that did not sit well with her embodied capital, her religious outlook as a Catholic. In the case of Pentecostalism, she felt particularly uneasy due to the focus on evil spirits, the Devil and exorcisms.

I had been raised a Catholic, but my godmother invited me to the IURD when I was a teenager and I liked the services there. I joined their youth group and stayed for several years, but then I started having visions, dark visions like the ones they talk about in their services - you know - the way they talk about demons and the work of the Devil ... and one day I had to be exorcised by the Pastor [...] it was horrible, horrible, horrible! I was really scared and never wanted to go back. I felt they were invoking the Devil and bringing him into my life.

While she was more comfortable with her experiences in an Umbanda church, after long-term 
exposure she decided that it "wasn't for me."

Then I had a boyfriend who practised Umbanda and he took me to his Afro-Brazilian temple - his mother was a priestess there - and she offered to close off my body [from evil spirits] ... after that ritual I continued going for a while... it was nice, it [the religion] helped calm me but eventually I moved away... it wasn't for me...I didn't really feel at home there.

As with migrants, due to the longer term nature of the religious consumption, embodied capital is more significant than objectified capital here and Janette's transits show how accrued embodied capital facilitates movement: thanks to her Catholic upbringing, she was able to use her Christian knowhow in the new religious setting of the IURD, and thanks to her exposure to spirit possessions at the IURD, she was able to transit to the mediunic Afro-Brazilian church with relative ease. However, similar to expatriate sojourners who move to new locations because of work relations, we see how Janette's sojourner transits were triggered by external factors (rather than internal as is the case for migrants), for instance her temporary stay in Umbanda because of her then boyfriend's religious affiliation. Due to the transit being more circumstantial, Janette did not put in the required effort to reframe her embodied capital, so the connection with the faith did not endure when her circumstances changed. This form of transit therefore starts to uncover some of the tensions at play between the various faiths, and the level of religious capital required for this transit to occur successfully.

\section{Religious consumers as shuttles}

Migrants and sojourners, although transiting between religions, are faithful to one religion at a time. Shuttles, however, practice two or more religions in parallel. Within our consumer typology, the shuttle is the most unconventional and therefore, much overlooked in the literature. Borrowing our metaphor from the shuttle device used in looms to weave the weft thread across the fixed strings in a continual to and fro motion, shuttle consumers weave rich patterns into the fabric of their religious identity thanks to their multifarious consumption of 
two or more religions at once. Shuttles are therefore in constant flux, moving between different religions and continually accruing more religious capital. The more religions they shuttle to and from, the more complex their religious identity. Unlike sojourners, who spend an extended period experiencing one faith at a time, shuttle consumers maintain a constant movement between their chosen religions and experience them in parallel. Of all the religious consumers, shuttles demonstrate the most commitment to their dual (or more) faiths in that they are not just visiting or trying out competing religions like tourists or sojourners but rather are defining themselves as loyal adherents to these religions.

Iandara comments on her dual religious identity, as she shuttles between Catholicism and Umbanda:

Ever since I can remember, I have been going to both, to the Catholic Church and the Umbanda temple. I feel that where there's love... where there's something more real, a closer [spiritual] connection, where people are not disconnected from the real world, then that is good... I don't like excess. I don't like strict dogmas. I don't like people controlling me. Too much control stifles me. Going to both [Catholic and Umbanda] makes me happy, I feel free.

As suggested by Janette's sojourning, certain religious permutations are more likely than others due to shared embodied and objectified capital. A common shuttle transit found in our data is that between Catholicism and Umbanda or Catholicism and Spiritism. Both Umbanda and Spiritism are syncretised with Catholicism thus sharing a cosmology (embodied capital) and iconography (objectified capital). Visually, representations of Jesus are prominent at both at Umbanda temples and Spiritist centres, therefore making these religions all the more relatable to Catholic consumers. Iandara is typical of shuttle consumers in that she brings this shared iconography back into her home, which boasts a syncretised altar with statuettes of Umbanda spirits next to the Virgin Mary and Jesus. Iandara also participates in activities at Catholic and Umbanda churches in tandem: “during festa junina [a traditional festivity celebrated in Brazil] I will go to church and light a candle to St John the Baptist for protection and then go to an Umbanda march for Xangô"; Xangô being the syncretised entity of St John the Baptist, 
representing the orixá (deity) of justice. In her religious transiting, Iandara effectively shuttles seamlessly between Catholicism and Umbanda.

In this way, we see how shuttles do not simply reframe their embodied capital in the way migrants do, but rather, superimpose their embodied capital for a more layered and complex religious identity. Again, this requires a deep understanding and engagement with their embodied capital and significant efforts (and creativity) in creating meaningful, overlapping narratives to reconcile the various religious doctrines. Although this is facilitated by institutional capital, it still requires significant work. As the second (or third) faith is adopted, new religious capital needs to be weaved into the religious identity in such a way as it complements, rather than contradicts, existing embodied capital. As we go through our typology, we therefore see a difference in both kind and degree of religious capital. This can be delineated in simplistic terms as: tourism being characterised by high levels of objectified capital, migration by significant levels of embodied capital, sojourning by lesser levels of embodied capital, and shuttling requiring the highest levels of embodied capital.

\section{Discussion: Moving Forwards (and backwards)}

\section{Religious Transits}

The findings of this research offer a number of contributions to both theory and practice. Theoretically, we expand on the concept of religious capital to explain how religious consumers can simultaneously practice various faiths, developing a consumer typology of four different forms of movement. In doing so, we recognise that there are different levels of commitment among these transiting religious consumers.

Unlike in most religious studies, which assume conversion, our data shows no radical break or shift from one fixed identity marker to another, rather, the transits are often subtle. Rather than only receiving a singular, dogmatic religious identity from an authoritative 
institutionalised religious source (as in Iannaccone's strict churches) or pursuing an internal, spiritual quest through adopting a multiplicity of incoherent spiritual traditions, styles and ideas (as in the New Age), we present a more syncretic alternative, simultaneous consumption of different institutionalised religions. While much of the religious literature discusses syncretic religions, our introduction of a shuttle consumer points to the syncretic consumer who, as befits the postmodern marketplace (Redden, 2016; Aupers \& Houtman, 2006) actively navigates between various market offerings to create their own personalised package. Whereas Üstüner and Holt's work (2007) explores shattered identity projects, our study reveals a multilayered religious identity, which is easily transferable to various settings, thanks to the ongoing accrual of religious capital.

We therefore argue that there is a need for a new mapping of the religious scene as the boundaries of popular religious consumption are being redrawn and we consider this paper only an exploratory attempt to consider some of these new realities. While Roof (1999) argued that the boundaries between faiths were becoming more blurred and that religious identities more malleable and multifaceted nearly two decades ago, there has been a paucity of research examining this beyond the New Age context. Although our data demonstrates a plural religious identity, with blurred boundaries between faiths, it is important to note that there are still certain underlying structures, it is not a free-for-all. While the focus of the paper did not examine Catholicism, as the dominant religion in the country, it was the primary religion for most of our informants and therefore was discussed at some length in our interviews. Although our data problematises the notion of a unitary religious identity as our religious consumers move around faiths, their core religious identity nonetheless remains (primarily) Catholic. For instance, our participants noted how they continue to follow certain Catholic sacraments (such as baptism, marriage, and so on) whilst participating in other faiths in parallel.

What we show is therefore that there is still a dominant faith acting as a stable anchor, 
which is grounded in the socio-cultural history of the country. As such religious identity is multi-layered rather than completely fluid, there is not complete freedom to choose. This faith is often taken for granted until faced with life-circumstances requiring new solutions at which point it provides the underlying scaffolding on which new forms of religious capital can be built. The transit is therefore not random but as Almeida and Montero (2001, p.93) find, "occurs in precise directions." While the literature tends to configure the spiritual supermarket (Roof, 1999) as a non-structure, we show that in our case there is a structure. Indeed, as we know from the retail literature, even in supermarkets consumers do not have free choice, there is unequal distribution and some products are more noticeable and accessible than others. We therefore show that movement in the religious marketplace occurs in certain directions due to the varying degrees of differentiation between the four faiths studied here. Some religions such as Candomblé and Umbanda have close-knit cosmologies and the routes between them are therefore more apparent than between more antagonistic religious pairs such as Candomblé and the IURD. Despite this apparent antagonism, we show that both religions benefit from the other's cosmology, incorporating it in various forms into their own faith. For example, the IURD appropriates ritual objects and procedures from Candomblé to attract new followers whilst still maintaining distance and affirming clear-cut differences, using those very ritual objects and procedures to demonstrate that they are more powerful.

As such, the marketplace is still competitive. Rather than strictness making religious organisations stronger and more attractive (Iannaccone, 1994), we argue that tolerance and flexibility are assets. Although these religions may appear as closed systems, they actually have different levels of openness. We thus dispel the idea that religions are bounded systems of belief and practice, with "insiders" who adhere and "outsiders" who do not, between which there can be no movement that is not boundary crossing (active conversion) and within which there can be no movement (just passive following). Rather, we demonstrate that relations 
amongst, and therefore the boundaries between the faiths, are constantly changing and adapting to the competition, ensuring a vibrant religious scene in Brazil. As such it is not just consumers' religious identities that undergo change but also those of the religions themselves: "not only does ideology shape behavior but also that behavior shapes ideology" (McAlexander et al., 2014, p.861). This moves us beyond the Western sociological idiom, which historically presumed stable, singular religious identities, reproducing the rigidity inherent to conversion. For the moment, this form of pluralistic religious consumption seems to be limited to emerging economies, however it could be a way forward for churches that are stagnating in the more mature markets of the Global North.

\section{Religious Capital}

Theoretically, we expand on the concept of religious capital to show how it can be applied to religious consumption in order to understand how religious consumers navigate postmodern marketplaces. In particular, this extension of religious capital offers theoretical explanation for how religious consumers can simultaneously practice various faiths. While the marketing literature on religious consumption has discussed religious and/or spiritual capital (e.g. Cova \& Cova, 2019; McAlexander, 2014), this has yet to be fully unpacked. Rather than a frozen picture, we provide a lived experience of movement, which is more faithful to our participants' realities.

In order for this mobility to be possible, a certain level of institutionalised religious capital is required. We already know that religion flourishes when it responds to changing social realities, however, there has been little recognition of the ways that more liberal, 'open' religions stimulate religious practice. By using similar vocabularies and drawing on common liturgies, the religious suppliers allow for a diverse religious transit. Unlike in Iannaccone's (1994) strict churches, our data shows a relaxing of institutional boundaries, where consumers 
are expected or even encouraged to move around the religious marketplace. This movement is made possible thanks to the overlapping of certain discourses and practices between religions and the acceptance of accrued religious capital from other faiths. This, in turn, means that consumers can relatively easily experience a new, different religious offering through numerous market-offerings. Rather than competing with one another, we see how some religions are presented as complementary (yet still differentiated).

Within our consumer typology, we demonstrate that varying levels of religious capital permit different configurations of religious consumption. In the initial exploration of other faiths, objectified capital is particularly important as it provides consumers with instantly visible reassurance due to shared iconography and rituals. This is therefore of particular importance of tourists, as they try out other religious offerings to complement their existing faith. The role of the market is therefore central to religious tourism, in line with the spiritual supermarket (Roof, 1999), facilitating movement between faiths by foregrounding material quick-fixes in the form of perfumed oils, herbs, candles and services such as personalised consultancies with church leaders. As (and if) religious consumers further explore new faiths, their objectified capital continues to facilitate movement between religions with more permanent use of the material and symbolic commodities of their faiths, sometimes using or presenting them simultaneously as is the case of Iandara with her syncretised altars. However, in order to move beyond simple tourism, religious consumers must make use of increasing levels of embodied capital. This requires more effort on the part of the religious consumer, as they actively reframe their existing religious identities and narratives to fit new faiths, whether through conversion, for migrants, or in a multi-layering process, for shuttles. This process has, of course, been facilitated by the overlapping cosmologies of the faiths studied through institutionalised capital, demonstrating how these forms of religious capital overlap in a circular process as the religious consumer moves up our typology in terms of levels of 
commitment. Moreover, as discussed above, at times there are barriers to transit, due to an inability by the consumer to reconcile their existing embodied capital with that required by another faith as we see in the case of sojourners.

\section{Implications for Marketing and Consumer Behaviour}

There is also, therefore, a sliding scale in terms of the degree of commitment, with some consumers transitioning between faiths as a temporary solution, when their current denomination falls short; while others live in a state of constant transition, consuming multiple faiths simultaneously. Our typology of consumer mobility serves to distinguish between these various forms of mobility, from tourists who show only weak levels of commitment and move around freely to shuttles who are deeply committed to two or more religious doctrines at once. While the weaker levels of commitment are not unfamiliar (tourism is similar to the notion of the spiritual supermarket which entails trying out various offerings and mixing and matching religious offerings, whereas migration is a form of conversion), there has been little research on longer-term, more permanent forms of commitment to two institutionalised religions or more. Our exploration of sojourner and shuttle religious consumers therefore contributes to marketing literature more broadly, thereby answering calls for further research on these transient consumers (Bardhi, Osteberg, \& Bengtsson, 2010), as a means of complementing already existing research on migrant consumers (Peñaloza, 1994). In a sense, what we see in our study is religious brandscape (Sherry, 1998), our religious consumers actively construct personal meanings and lifestyle orientations, not from a single religion, but rather from an array of religions in complex, multifaceted ways. It is therefore necessary to consider how these religions interact - and conflict - with each other. Generally, as we show, consumers experience little tension in their consumption of religions which are seemingly at odds with each other. Instead, our study shows how consumers are able to create narratives that bring the 
various religions together into a shared discourse rather than focusing on any differences between them. Our consumer typology may therefore also have utility in other consumption spheres in terms of how consumers construct their identity in various types of brandscapes.

\section{Limitations and Further Research}

While our data shows that religious transit is not unique to either marginalised or privileged classes, further research is needed to unpack the perceived differences between the religions. Verter (2003) suggests a social incentive in denominational mobility, where switching religions can facilitate social upward mobility for the consumer. This sense of social mobility seduced much of the Brazilian bourgeoisie at the end of the $19^{\text {th }}$ century, when Spiritism was adopted as a sophisticated and pseudo-scientific alternative to Afro-Atlantic faiths, common among the working class (Capone, 2010). From our own fieldwork, it was clear that Spiritism is well regarded amongst the higher echelons of Brazilian society, with Spiritist centres prominently located in upper class neighbourhoods, whereas Candomblé houses tended to be in the periphery of the city and much more discreet about their religious practice. Further unpacking of the demographics visiting the various churches is therefore needed in order to examine whether there are socio-demographic drivers to religious mobility. Due to the small number of participants interviewed, we could not discern any clear trends. Examining class dynamics may help further explicate the areas of tension in the religious transit and how consumers deal with this tension. Future empirical research is also needed to test our consumer typology across different forms of religious consumption.

Due to the methods employed, the focus of this paper is on individual religious consumers. There is therefore a need to consider the socialisation process more fully. Indeed, the selection of one spiritual product over another is determined by social variables. Some of our data revealed social factors that lead to subsequent religious transit, such as friends 
introducing people to new faith systems, especially during a time of emotional or physical need. In the case of sojourners we also see how social factors can ultimately put a stop to religious mobility, for example through break-ups. This social element could be unpacked further. Indeed, the religious market, like any market, exists in specific configurations embedded in and contingent upon broader social and institutional relationships. 


\section{References:}

Almeida, R. (2004). Religião na Metrópole Paulist. Revista Brasileira de Ciencias Sociais, 19(56), 16-27.

Almeida, R. (2006). A expansão pentecostal: circulação e flexibilidade. In Teixeira, F., and Menezes, R. (Eds.) As religiões no Brasil: continuiddades e rupturas. Petropolis: Vozes.

Almeida, R. (2009). A Igreja Universal e seus Demônios: Um Estudo Etnográfico. São Paulo: Editora Terceiro Nome.

Almeida, R. \& Monteiro, P. (2001). Trânsito religioso no Brasil'. São Paulo em Perspectiva, 15 (3), 92-101.

Altglas, V. (2014). From Yoga to Kabbalah: Religious Exoticism and the Logics of Bricolage. Oxford: Oxford University Press.

Amoruso, M. (2018) Spaces of Suffering: Religious Transit in São Paulo’s Devotion to Souls. Journal of the American Academy of Religion, lfy016. doi: /10.1093/jaarel/lfy016

Arber, A. (2006). Reflexivity: A Challenge for the Researcher as Practitioner? Journal of Research in Nursing, 11 (2), 147-157. doi:10.1177/1744987106056956

Arnold, S.J. \& Fischer, E. (1994). Hermeneutics \& Consumer Research. Journal of Consumer Research, 21(1), 55-70. doi:10.1086/209382

Arnould, E., Price, L. \& Otnes, C. (1999). Making Magic Consumption: A Study of WhiteWater River Rafting. Journal of Contemporary Ethnography, 28(1), 33-68. doi:10.1177/089124199129023361

Arsel, Z. \& Thompson, C. (2011). Demythologizing Consumption Practices: How Consumers Protect Their Field-Dependent Identity Investments from Devaluating Marketplace Myths. Journal of Consumer Research, 37 (5), 791-806. doi:10.1086/656389

Bardhi, F., Ostbeg, J., \& Bengtsson, A. (2010). Negotiating cultural boundaries: Food, travel and consumer identities. Consumption Markets \& Culture, 13 (2), 133-157.

Atkin, D. (2004). The Culting of Brands - when customers become true believers. London: Portfolio, Penguin Books Limited.

Aupers, S. \& Houtman, D. (2006) Beyond the Spiritual Supermarket: The Social and Public Significance of New Age Spirituality, Journal of Contemporary Religion, 21 (2), 201222. doi:10.1080/13537900600655894

Belk, R. \& Tumbat, G. (2005). The cult of Macintosh. Consumption, Markets and Culture, 8 (3), 205-217. doi:10.1080/10253860500160403

Belk, R. \& Costa, J.A. (1998). The Mountain Man Myth: A Contemporary Consuming Fantasy. Journal of Consumer Research, 25 (3), 218-240. doi:10.1086/209536

Belk, R., Wallendorf, M. \& Sherry, J. Jr. (1989). The Sacred and the Profane in Consumer Behavior: Theodicy on the Odyssey. Journal of Consumer Research, 16 (June), 1-38. doi:10.1086/209191

Benton, R. Jr.(2016). Religion and Macromarketing. Journal of Macromarketing, 36 (4), 373376. doi:10.1177/0276146714533446

Berger P. L. (1967). The Sacred Canopy. Doubleday: New York.

Bonsu, S. \& Belk, R. (2003) Do not go cheaply into that Good Night: Death-Ritual Consumption in Aasante, Ghana. Journal of Consumer Research, 30 (June), pp. 41-55. doi:10.1086/374699

Bonsu, S. \& Belk, R. (2010). Marketing a new African God: Pentecostalism and Material Salvation in Ghana. International Journal of Nonprofit and Voluntary Sector Marketing, 15, 305-323. doi:10.1002/nvsm.398

Bourdieu, P. (1986). The Forms of Capital. In Richardson, J.G. (Ed.) Handbook of Theory and Research for the Sociology of Education. New York: Greenwood, 241-58.

Bourdieu, P. (1991). Language and Symbolic Power. Cambridge, UK: Polity Press. 
Bowman, M. (1999). Healing in the Spiritual Marketplace: Consumers, Courses and Credentialism. Social Compass, 46 (2): 181-189. doi:10.1177/003776899046002007

Brandão, C. R. (1994) A Crise das instituições tradicionais produtoras de sentido. In Moreira, A. \& Zicman, R. (Eds.) Misticismo e Novas Religiões, Petrópolis: Vozes, 23-41.

Bruce, S. (2014). Authority and Freedom: economics and Secularization. In Jean-Claude Usnier and Jörg Stolz, eds., Religions as Brands: New Perspectives on the Marketization of Religion and Spirituality, London: Routledge, 191-204.

Capone, S. (2010). Searching for Africa in Brazil - Power and Tradition in Candomblé. London: Duke University Press.

Cimino, R. \& Lattin, D. (1999). Shopping for Faith: American Religion in the New Millennium. San Francisco, CA: Josey-Bass.

Coffey, A. (2002). Ethnography and Self: reflections and representations. In May, T. (Ed.) Qualitative Research in Action, London: Sage Publications, 313- 331.

Corcoran, K. E. (2012). Religious Human Capital revisited: Testing the effect of religious human capital on religious participation. Rationality and Society, 24 (3), 343-379. doi: $10.1177 / 1043463112453550$

Corten, A., Dozon, J. P., \& Oro, A. P. (2003). Introdução. In A. P. Oro, A. Corten \& J.P. Dozon (Eds.), Igreja Universal do Reino do Deus - os novos conquistadores da fé (pp. 1345). São Paulo: Paulinas, 13-45.

Cova, V. \& Cova, B. (2019, forthcoming). Pain, suffering and the consumption of spirituality: a toe story. Journal of Marketing Management. doi:10.1080/0267257X.2018.1559872

Crockett, D. \& Davis, L. (2016). Commercial Mythmaking at the Holy Land Experience. Consumption Markets \& Culture, 19 (2), 206-27. doi:10.1080/10253866.2015.1081849

Drenten, J., \& McManus, K. (2016). Religion-Related Research in the Journal of Macromarketing, 1981-2014. Journal of Macromarketing, 36 (4), 377-387.

Duarte, S. (2001). Religious Transit and Ecological Spirituality in Brazil. CENSUR (Center for Studies on New Religions) [online] available at: http://www.cesnur.org/2001/london2001/duarte.htm

Eckhardt, G. M., \& Mahi, H. (2012) Globalization, Consumer Tensions, and the Shaping of Consumer Culture in India. Journal of Macromarketing, 32 (3), 280-294. doi:10.1177/0276146712440708

Einstein, M. (2007). Brands of Faith: Marketing Religion in a Commercial Age, New York: Routledge.

Einstein, M. (2013). Branding Faith and Managing Reputations. In D. Rinallo, L. Scott, \& P. Maclaran (Eds.), Consumption and Spirituality, New York: Routledge, 132-145.

Fernandez, K. V., \& Lastovicka, J. L. (2011). Making magic: Fetishes in contemporary consumption. Journal of Consumer Research, 38 (2), 278-299. DOI: 10.1086/659079

Finke, R. (2003). Spiritual Capital: Definitions, Applications, and New Frontiers. Spiritual Capital Planning Meeting [online] available at: http://www.metanexus.net/archive/spiritualcapitalresearchprogram/pdf/finke.pdf

Finke, R. \& Stark, R. (1988). Religious Economies and Sacred Canopies: Religious Mobilization in American Cities, 1906. American Sociological Review, 53 (1), 41-49. doi:10.2307/2095731

Firat, F., Dholakia, N. \& Venkatesh, A. (1995). Marketing in a postmodern world. European Journal of Marketing, 29 (1), 40-56. doi:10.1108/03090569510075334

Giddens, A. (1990). The Consequences of Modernity. Cambridge, UK: Polity Press.

Gould, S. (2006). Cooptation through conflation: Spiritual materialism is not the same as spirituality. Consumptions, Markets and Culture, 9 (1), 63-78. doi.org/10.1080/10253860500481262 
Gullekson, N. L., \& Vancouver, J. B. (2010). To conform or not to conform? An examination of perceived emotional display rule norms among international sojourners. International Journal of Intercultural Relations, 34 (4), 315-325.

Hackley, A. \& Hackley, C. (2016). Death Ritual and Consumption in Thailand: Insights from Pee Ta Kohn Hungry Ghosts Festival. In Dobscha, S. (Ed.), Death in a Consumer Culture. London: Routledge, 91-107.

Heelas, P. (1996). The New Age Movement. Oxford: Blackwell.

Hirschman, E. C. (1981). American Jewish ethnicity: Its relationship to some selected aspects of consumer behaviour. Journal of Marketing, 45 (3), 102-110. doi:10.2307/1251545

Houtman, D., \& Aupers, S. (2007). The spiritual turn and the decline of tradition: The spread of post-Christian spirituality in 14 Western countries, 1981-2000. Journal for the Scientific Study of religion, 46(3), 305-320. doi:10.1111/j.1468-5906.2007.00360.x

Husemann, K.C.\& Eckhardt, G.M. (2018). Consumer Deceleration. Journal of Consumer Research, doi:10.1093/jcr/ucy047

Iannaccone, L. R. (1994). Why Strict Churches Are Strong? American Journal of Sociology, 99 (5), 1180-1211. doi:10.1086/230409

Iannaccone, L. R. (1990). Religious Practice: A Human Capital Approach. Journal for the Scientific Study of Religion, 29 (3), 297-314. doi:10.2307/1386460

Izberk-Bilgin, E. (2012). Infidel brands: Unveiling alternative meanings of global brands at the nexus of globalization, consumer culture, and Islamism. Journal of Consumer Research, 39 (4), 663-687. doi:10.1086/665413

Kale, S. H. (2004). Spirituality, Religion, and Globalization. Journal of Macromarketing, 24 (2), 92-107. doi:10.1177/0276146704269296

Kelley, D. M. (1986). Why Conservative Churches Are Growing: A Study in the Sociology of Religion. Macon, Ga.: Mercer University Press.

Knoblauch, H. (2008). Spirituality and Popular Religion in Europe. Social Compass, 55 (2), 140-153. doi:10.1177/0037768607089735

Liu, X. \& Shaffer, M.A. (2005). An Investigation of Expatriate Adjustment and Performance: A Social Capital Perspective. International Journal of Cross Cultural Management. 5 (3), 235-254. doi/10.1177/1470595805058411

Maclaran, P., Belk, R., Gould, S., Izberk-Bilgin, E., Kedzior, R., Kozinets, R.V., Schau, H.J., Scott, L., Sherry, J.F., \& Arnould, E. (2012). Conversations on the Sacred and Spirituality in Consumer Behavior. In NA-Advances in Consumer Research, 40, Association of Consumer Research, 1094-1095.

Magliocco, S. (2004). Witching Culture: Folklore and Neopaganism in America. Philadelphia: University of Pennsylvania Press.

Mason, J. (2002) Qualitative Researching. London, UK: Sage Publications.

Mathras, D., Cohen, A., Mandel, N. \& Mick, D. (2016). The Effects of Religion on Consumer Behavior: A Conceptual Framework and Research Agenda. Journal of Consumer Psychology, 26 (2), 298-311. doi:10.1016/j.jcps.2015.08.001

McAlexander, J., Dufault, B., Martin, D. \& Schouten, J. (2014). The Marketization of Religion: Field, Capital, and Consumer Identity. Journal of Consumer Research. 41, 3, 858-75. doi:10.1086/677894

McCracken, G. (1988). The Long Interview. Qualitative Research Methods, Vol. 13, London: Sage Publications.

McCutcheon, R. (1999). The Insider/Outsider Problem in the Study of Religion, London: Cassell.

Miller, K. D. (2002). Competitive Strategies of Religious Organizations. Strategic Management Journal, 23, 435-456. doi:10.1002/smj.234 
Miller, V. (2004). Consuming Religion: Christian Faith and Practice in a Consumer Culture. New York: Continuum.

Mittlestaedt, J. D. (2002). A Framework for Understanding the Relationships between Religions and Markets. Journal of Macromarketing, 22 (1), 6-18. doi:10.1177/027467022001002

Moore, R. L. (1994). Selling God: American Religion in the Marketplace of Culture. Oxford: Oxford University Press.

Moufahim, M. (2016). Authenticity, religious identity and consumption: a reflexive (auto)ethnographic account. In Islam, marketing and consumption: critical perspectives on the intersections. Abingdon, Oxon: Routledge, 173-193.

Mulcock, J. (2001). Creativity and Politics in the Cultural Supermarket. Continuum. 15(2): 169-185. doi:10.1080/713657800

Muñiz, A.M. Jr. \& Schau, H. J. (2005). Religiosity in the Abandoned Apple Newton Brand Community. Journal of Consumer Research, 31 (3), 737-747. doi:10.1086/426607

Myers, E. (1990). Wellness through the lifespan. Guidepost, 23:11.

O'Guinn, T. C. \& Belk, R. (1989). Heaven on Earth: Consumption at Heritage Village, USA. Journal of Consumer Research. 16 (2), 227-38. doi:10.1086/209211

Peñaloza, L. (1994). Atravesando fronteras/Border Crossings: A Critical Ethnographic Exploration of the Consumer Acculturation of Mexican Immigrants. Journal of Consumer Research. 21 (1), 32-54.

Peñaloza, L. \& Cayla, J. (2006). Writing pictures/taking fieldnotes: An exploration of the properties and relative roles of fieldnotes and photographs in studying market aesthetics. Handbook of qualitative research methods in marketing, 279-290.

Pew Forum. (2012). The global religious landscape. Retrieved from http://www.pewforum.org/2012/12/18/global-religious-landscape-exec/ (accessed on 26.11.2017)

Prayag, G., Mura, P., Hall, M. \& Fontaine, J. (2015). Drug or spirituality seekers? Consuming Ayahuasca. Annals of Tourism Research. 52, 175-177. doi:10.1016/j.annals.2015.03.008

Rabelo, M. (2015). Moving between Religions in Brazil: Space and the Analysis of Religious Trajectories. Current Anthropology, 56 (6), 848- 864. doi:10.1086/684013

Redden, G. (2016). Revisiting the spiritual supermarket: does the commodification of spirituality necessarily devalue it? Culture and Religion. 17 (2), 231-249. doi:10.1080/14755610.2016.1183690

Richelieu, A. \& Korai, B. (2012). The international expansion of religious organizations in Africa. International Journal of Nonprofit and Voluntary Sector Marketing. 17 (2), 144-155. doi:10.1002/nvsm.1418

Rinallo, D., Borghini, S., Bamossy, G. \& Kozinets, R. (2013). When Sacred Objects Go $\mathrm{B} 囚 \mathrm{a}(\mathrm{n}) \mathrm{d}$ : Fashion Rosaries and the Contemporary Linkage of Religion and Commerciality. In Rinallo, D., Scott, L. \& Maclaran, P. (Eds.) Consumption and Spirituality, (pp. 29-40) New York: Routledge.

Rinallo, Diego, Pauline Maclaran, and Lorna Stevens (2016). A mixed blessing: Marketmediated Religious Authority in Neopaganism. Journal of Macromarketing, 36 (4), 425-442. doi:10.1177/0276146716655780

Robbins, J. (2004). The globalization of Pentecostal and charismatic Christianity. Annual Review of Anthropology, 33, 117-143. doi:10.1146/annurev.anthro.32.061002.093421

Roof, W. (1999). Spiritual Marketplace: Baby Boomers and the Remaking of American Religion. Princeton, NJ: Princeton University Press. 
Sanchis, P. (2001). Religiões, religião... Alguns problemas do sincretismo no campo religioso brasileiro. In Sanchis, P. (Ed.) Fiéis \& Cidadãos: Percursos de Sincretismo no Brasil. (pp. 9-57). Rio de Janeiro: Universidade do Estado do Rio de Janeiro, EDUERJ.

Scott, L. \& Maclaren, P. (2013). Consuming the Mists and Myths of Avalon: A Case Study of Pilgrimage in Glastonbury. In Rinallo, D., Scott, L. \& Maclaran, P. (Eds.) Consumption and Spirituality, New York: Routledge, 195-207.

Schneiders, S.M. (1989). Spirituality in the academy. Theological Studies, 50 (4), 676-697.

Schouten, J. W. \& McAlexander, J. H. (1995). Subcultures of Consumption: An Ethnography of the New Bikers. Journal of Consumer Research. 22 (1), 43-61. doi:10.1177/004056398905000403

Sherry, J. F. (1998). Servicescapes: the Concept of Place in Contemporary Markets, Lincolnwood, Ill: NTC Business Books.

Sherry, J.F. \& Kozinets, R.V. (2007). Comedy of the Commons: Nodamic Spirituality and the Burning Man Festival. In Russell W. Belk, John F. Sherry (Eds.) Consumer Culture Theory (Research in Consumer Behavior, Volume 11) Emerald Group Publishing Limited, 119-147.

Shirazi, F. (2016). Brand Islam: The Marketing and Commodification of Piety. Austin, TX: University of Texas Press.

St James, Y., Handleman, J.M. \& Taylor, S.F. (2011). Magical Thinking and Consumer Coping. Journal of Consumer Research, 38, (4), 1 632-649. doi:10.1086/660163

Stark, R. \& Finke, R. (2000). Acts of Faith: Explaining the Human Side of Religion. Oakland, CA: University of California Press.

Steil, C. A. (2001). Pluralismo, modernidade e tradição: transformações do campo religioso. Ciencias sociales y religión. Porto Alegre, RS. 3 (3) (oct. 2001), 115-129.

Thompson, C. (1997). Interpreting Consumers: A Hermeneutical Framework for Deriving Marketing Insights from the Texts of Consumers' Consumption Stories. Journal of Marketing Research, 34 (4), 438-455. doi:10.2307/3151963

Tung, R. L. (1998). American expatriates abroad: From neophytes to cosmopolitans. Journal of World Business, 33 (2), 125-144.

Twitchell, J. B. (2005). Branded Nation: The Marketing of Megachurch, College Inc., and Museumworld. New York: Simon \& Schuster.

Twitchell, J. (2007). Shopping for God: How Religion went from In your Heart to In your Face. New York: Simon and Schuster.

Urban, H. B. (2000). The Cult of Ecstasy: Tantrism, the New Age, and the Spiritual Logic of Late Capitalism. History of Religions 39(3): 269-304. doi:10.1086/463593

Üstüner, T. \& Holt, D. (2007). Dominated Consumer Acculturation: The Social Construction of Poor Migrant Women's Consumer Identity Projects in a Turkish Squatter. Journal of Consumer Research, 34 (1), 41-56. doi:10.1086/513045

Van Maanen, J. (1988). Tales of the field: On writing ethnography. Chicago, IL: University of Chicago.

Van Maanen, J. (2011). Ethnography as Work: Some Rules of Engagement. Journal of Management Studies, 48 (1), 218- 234. doi:10.1111/j.1467-6486.2010.00980.x

Verter, B. (2003). Spiritual Capital: Theorizing Religion with Bourdieu against Bourdieu. Sociological Theory, 21 (2), 150-174. doi:10.1111/1467-9558.00182

Yip, J.\& Ainsworth, S. (2016). "Whatever Works": The Marketplace Mission of Singapore's City Harvest Church, Journal of Macromarketing, 36 (4), 443-456. doi:10.1177/0276146716641990

Winkelman, M. (2005). Drug Tourism or Spiritual Healing? Ayahuasca Seekers in Amazonia. Journal of Psychoactive Drugs, $37 \quad$ (2), 209-218. doi:10.1080/02791072.2005.10399803 


\section{Appendix A: Focal Religions}

\begin{tabular}{|c|c|}
\hline Religion & Characteristics \\
\hline $\begin{array}{l}\text { Pentecostalism } \\
\text { (focus on } \\
\text { IURD) }\end{array}$ & $\begin{array}{l}\text { The IURD (International Church of the Kingdom of God, or Igreja } \\
\text { Universal do Reino de Deus) is a Pentecostal mega-church founded by } \\
\text { Edir Macedo with its headquarters in the oversized replica of the Biblical } \\
\text { Temple of Solomon in São Paulo. Practices include exorcisms, faith } \\
\text { healing, charismatic preaching, and the gospel of prosperity. Lengthy } \\
\text { daily services have prayers, collective blessings, the use of testimonials, } \\
\text { and monetary offerings to the church (tithing and other financial } \\
\text { sacrifices). Strong use of Judaic imagery in architecture, decoration, } \\
\text { clothing of church leaders and general aesthetics. Use of multimedia } \\
\text { including televangelism, radio and popular programming. }\end{array}$ \\
\hline Spiritism & $\begin{array}{l}\text { Also known as Kardecism. Syncretic religion started by } 19 \text { th century } \\
\text { French educator Hippolyte Léon Denizard Rivail using the pen-name } \\
\text { Allan Kardec. Healing-based focus in } 50 \text { non-profit 'hospitals' in Brazil } \\
\text { dealing primarily in improving mental health through faith healing, spirit } \\
\text { mediums, clairvoyants, and faux surgeries. Other practices and beliefs } \\
\text { include cleansing, homeopathy, reincarnation, chakras, trances, and the } \\
\text { perispirit. Participants receive individual attention and dress in white for } \\
\text { 'surgeries.' }\end{array}$ \\
\hline $\begin{array}{l}\text { Candomblé } \\
\text { (Afro- } \\
\text { Brazilian) }\end{array}$ & $\begin{array}{l}\text { Candomblé is a polytheistic syncretic religion that was brought to Brazil } \\
\text { from West Africa during the slave trade. Like Santería in Cuba, } \\
\text { Candomblé worships African orixás or spirits and places spirit possession } \\
\text { at the heart of its religious practice. The faith originated in Salvador, } \\
\text { Bahia and spread to different parts of the country. The first Candomblé } \\
\text { houses (or terreiros) established in Salvador date back to the start of the } \\
19^{\text {th }} \text { century, although the religion has a longer history of enslavement } \\
\text { and mass-deportation of Africans of different ethnic backgrounds to } \\
\text { Brazil. Candomble is considered a creolisation of Yoruba, Ewe and Bantu } \\
\text { beliefs and the priests and priestesses (mães and pais de santo) of } \\
\text { Candomblé houses, along with adherents, are devoted to the preservation } \\
\text { of the African roots of religion. Practices include spirit mediums, animal } \\
\text { sacrifice, herbal medicinal healing, summoning spirits with drumming } \\
\text { and singing, trance dancing, communicating with the oracle (via shell } \\
\text { readings) and heavily adorned altars. }\end{array}$ \\
\hline $\begin{array}{l}\text { Umbanda } \\
\text { (Afro- } \\
\text { Brazilian) }\end{array}$ & $\begin{array}{l}\text { An authentically Brazilian syncretic faith, Umbanda was established at } \\
\text { the start of the 20th century in Rio de Janeiro. Described by some as a } \\
\text { 'whitened' version of more Africanised Candomblé, it lacks animal } \\
\text { sacrifice, pouring blood and/or drink on idols, rigorous initiation } \\
\text { processes, and the high fees associated with Candomblé. In addition to } \\
\text { Catholicism, it combines elements of Kardecism including mediumship, } \\
\text { spirit possession, karma and reincarnation. As well as recognising and } \\
\text { worshiping the natural forces (or orixás) of Candomblé - which } \\
\text { Umbanda equates to Catholic saints - it also venerates an array of spirits, } \\
\text { including: pretos vellhos (old black slaves), caboclos (Amerindians), } \\
\text { Pomba Gira (a female gypsy spirit), and Zé Pilintra (a Bahianan male } \\
\text { rascal dressed in white). Such spirits are called upon during ritualised } \\
\text { incorporation ceremonies to offer help and consultancy to humans. }\end{array}$ \\
\hline
\end{tabular}




\section{Appendix B: Offering for Ogum - to open our paths to successful publications}

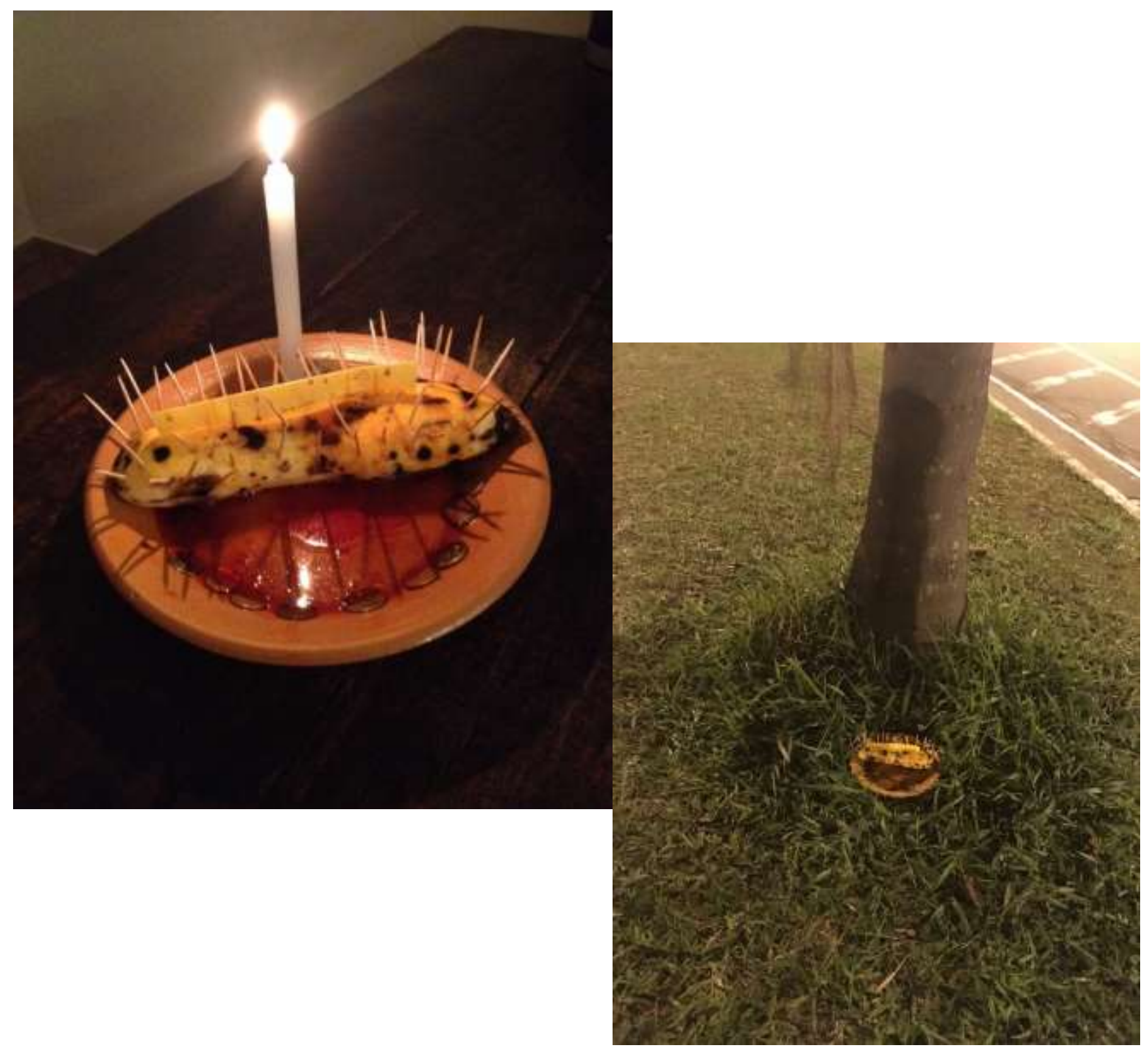

For this offering we need to purchase a local root vegetable, similar to a cassava, steam it, use toothpicks to pierce it, place it in a terracotta bowl, drench it with dendê oil, honey and beer (Ogum's favourites), place coins around it and light a white candle overnight while it soaks up the ingredients and energy. On the following day, once the candle has died out, we must place our offering to Ogum in a busy intersection (to open our paths) and specifically under a tree. When placing it under the tree, we must further invoke the spirit by crouching down and clapping 7 times in three intervals.

[Fieldnotes, July 2017] 


\section{Appendix C: Reflections on Conducting Religious Research}

The vantage point of the two authors differed substantially, allowing for a careful negotiation of 'closeness' and 'distance' in the fieldwork (Arber, 2005; see also Moufahim, 2016). The first author's own Latin American (although not Brazilian) ethnicity provided a preunderstanding of Afro-Atlantic religions, how these polytheistic faiths have syncretised over the years with Catholicism, and how popular religions are tightly woven into adherents' daily livelihoods in Latin America, whilst at the same time avoiding any potential sociocultural prejudices towards Brazilian religions. Beyond this familiarity with African diaspora faiths and the practice of popular religiosity in Latin America, the first author felt a particular affinity with some of church services of the study, given her personal circumstances at the time. Thanks to their psychotherapeutic and personalised approach, the various religious services offer consumers individualised and tangible solutions to their problems, providing them with the positive psychology and sense of empowerment needed to cope with life's challenges. The first author's fieldnotes reveal a strong sense of self-introspection and a reflexive spiritual journey, where she positioned herself within the research context and became familiar with the field (Coffey, 2002), acknowledging the benefits of transiting freely across several faiths in the pursuit of solutions. This echoes Rinallo et al. (2016, p.430) in their claim that the spiritual marketplace "can hardly be studied by scholars who remain at the margin of core awarenessinducing experiences," advocating instead for a participatory and immersive approach in the field. In her studies on African faiths in Brazil, Capone (2010, p.24) similarly argues for the need for the researcher to locate him/herself in the symbolic universe under study, wondering "where does research end and belief begin?" As a counterpoint, the second author, although atheist, had a familiarity with Catholicism but brought a fresh outlook on the four faiths studied in this paper. Despite this lack of previous knowledge, she was able to participate fully in the various market-mediated services and rituals, demonstrating the ease with which these offerings can be solicited. The study therefore benefits from a mixed insider/outsider approach, by carefully balancing "positive embracement [with] passionate criticism" for a more cohesive "method of compassion" (Salomonsen cited in Rinallo et al., 2016, p.430). In particular, we follow from Magliocco (2004, p.15) in that we argue an ethnographic perspective "is not about being an objective observer of a culture, but rather about containing within one body multiple, simultaneous frames of reference with which to interpret experience, and being able to shift easily from one to another." 


\section{Appendix D: 'Religious Transit' map given to interview participants}

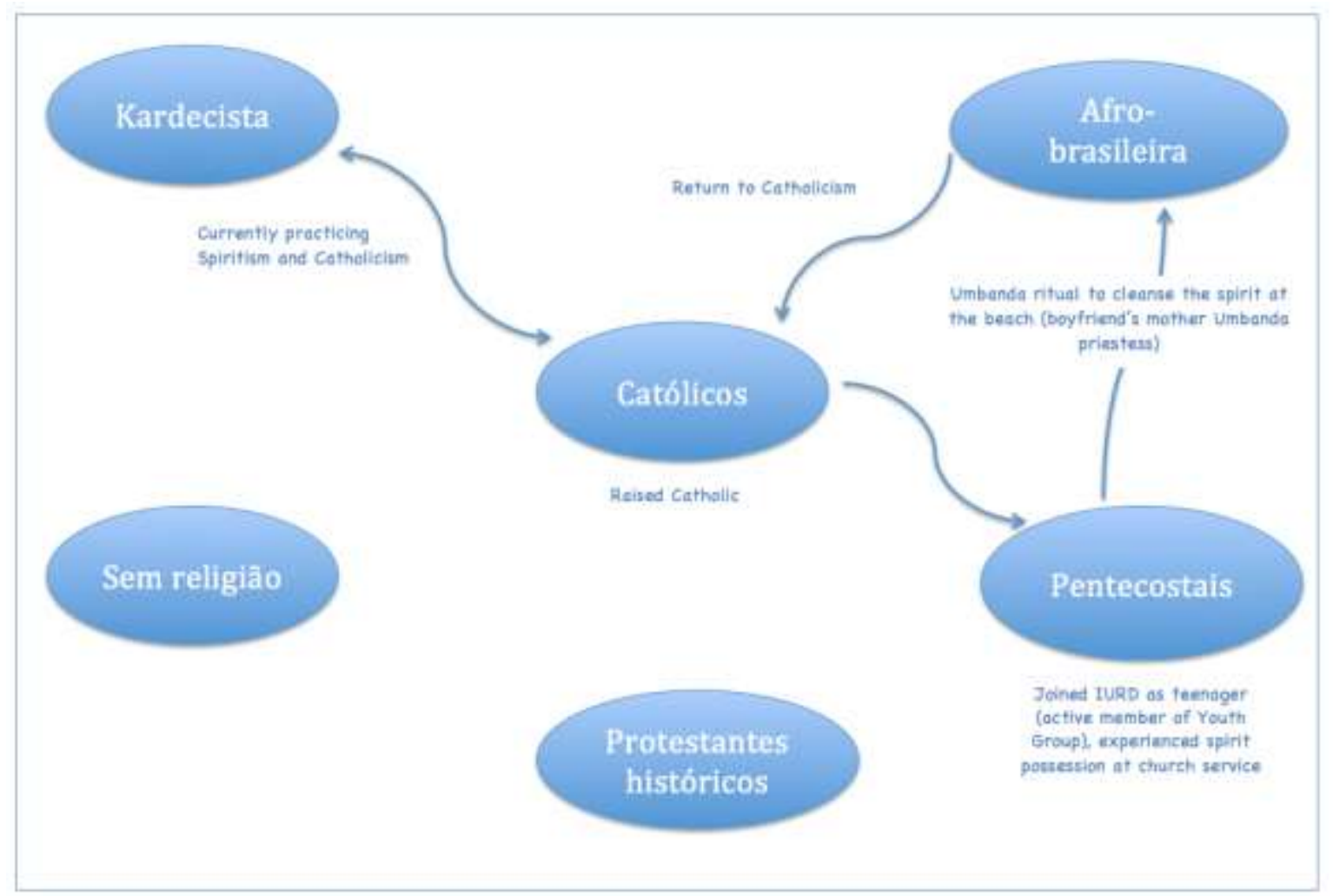

Adapted from Almeida (2004, p. 17) visual stimulus to map respondents' migration between different religions. This example shows Janette's religious journey. 